\title{
Research on Loss Signs of Listed Companies Based on External Viewpoint in China
}

\author{
Yong $\mathrm{Du}^{1}$, Ailin Xiong ${ }^{1} \&$ Bo Yan $^{2}$ \\ ${ }^{1}$ School of Economics and Management, Southwest University, Chongqing, China \\ ${ }^{2}$ Economics and Management School, Ocean University of Gudong, Zhanjiang, China \\ Correspondence: Bo Yan, School of Economics and Management, Ocean University of Gudong, Zhanjiang, \\ 524088, China. Tel: 136-5286-7827. E-mail: dy772012@126.com
}

Received: November 21, 2013

Accepted: December 11, 2013 Online Published: December 23, 2013

doi:10.5539/ijef.v6n1p217

URL: http://dx.doi.org/10.5539/ijef.v6n1p217

\begin{abstract}
This article respectively carries out the research on the audit opinion of certified public accountants, capital market efficiency, product market changes, macro-economic cycles, and the degree of industry boom based on the study of outside perspective. It thinks investors not only concern about the symptoms of loss shown in the operations within the company but also pay more attention to the external signs shown in all aspects of the company's losses. Because there is no "internal control" phenomenon in the sign of the external loss, therefore, the external signs of a loss can conduct a more accurate identification and early warning of losses of listed companies.
\end{abstract}

Keywords: external viewpoint, audit opinions, industry boom degrees, loss symptoms

\section{Introduction}

Previous scholars all consider the internal factors for the study of loss symptoms or troubled company, ignoring the external factors may indicate the company losses. The author thinks that, the changes in the external environment such as the auditing opinions of certified public accountants, the industry situation of a company, the capital market and product market can also identify loss incurred in the case of listed companies. The article here focus on consideration of the external audit opinion, capital market efficiency, market change, macro economic cycle, industry boom degrees affect its operating performance.

\section{The Loss Signs of Audit Opinions}

According to the auditing standards, certified public accountants should express an audit opinion after the implementation of the audit procedures to the auditees. The process includes the auditors internal control audit and evaluation, on the basis of it can determine the effectiveness of internal control, so that they can learn the truth of accounting information. According to going concern audit criterion, factors that affect enterprise continuing operations include the cumulative operating huge loss, insolvency, cannot repay debts, negative working capital, fails to fulfill the maturity of the loan contract, exist for contingent liabilities of foreign large guarantee, etc, Which are the cause of enterprise financial crisis. When the corporate existence of these may lead to its ability to continue as a going concern significant events or circumstances, if on the basis for the auditor's professional judgment, the preparation of the financial statements of the auditees on the basis of the going concern assumption is reasonable, and the financial statements are fully disclosed, the auditor should issue an unqualified audit opinion, and in the opinion increased emphasis of matter paragraph after paragraph; if inadequate disclosure, the auditor should issue a qualified opinion or an adverse opinion; In extreme cases, if the existence of significant accounting statements have multiple uncertainties, the auditor will express no opinion. When the existence of the business factors that affect business continuity will, generally try to avoid their real situation and make a full disclosure of appropriate evaluation, as this will have very serious negative business impact. In this case, the motivation of enterprise surplus management will be stronger. Therefore, when a listed company's financial risk increases, the auditor in order to reduce or circumvent its own audit risk, are more likely to issue a non-standard audit opinion. The standard advice here is without any explanation, emphasis of matter, or any modification of the terms of an unqualified audit opinion, the rest for the non-standard audit opinion. From this perspective, the type of audit opinion can also reflect a sign of financial distress to some 
extent.

\section{The Loss Signs of Capital Market}

The loss signs of listed companies in the capital market have two main aspects:

\subsection{The Listed Companies'Share Price Tumbled}

The market shares price of the listed companies, from one side reflect the investors' confidence in the investment of listed companies. If investors are bullish on the development trend of the future of the listed companies, they may do an additional investment, causing the company's share price raised; on the contrary, shares price will tumble owing to lack of confidence. Moreover, the share price plummeted will cause other investors to have poor expected, which continue to have a more negative impact on share price. And, once lost the confidence of investors, listed companies will be difficult to raise capital from the stock market again. At the same time, with the company image damaging, banks and other credit institutions and creditors are unwilling to provide funds to the company, which makes the company's financing risk increase, may cause the capital chain to break, cannot repay maturing debt and other serious consequences, can easily lead to the company fall into financial crisis, resulting in financial failure. Therefore, we can view the stock plunged as one of the important signs of the listed companies' losses.

\subsection{The Large and Controlling Shareholder's Equity Transfer}

Equity transfer of listed companies, especially large shareholder, the controlling shareholder's equity changes, usually starts at the beginning of the company's operating condition or has deteriorated. Its purpose is for big shareholders to make company and themselves out of trouble to look for a powerful partner. Such as restructuring of listed companies mostly begin at the equity transfer. Since equity transfer is a property changes behavior, the shareholders based on shareholder status transferred all the same rights and obligations to the assignee after equity transfer, the assignee has therefore become shareholder of the company. While obtaining shareholders' rights, the operations deterioration of the responsibilities and obligations undertaken by the original shareholders of the transfer are also fulfilled by the assignee for the company's equity owners in order to evade responsibility, against loss. As a result, we can also view large shareholder, the controlling shareholder's equity transfer behavior as one of the signs of the listed companies' loss.

\section{The Loss Signs of Products on the Market}

Product markets generally include product sales market and supply market. When the listed companies are impending loss, signs of performance in both markets are as follows:

\subsection{Sales Market Share Reduced and Hard to Attract New Customers}

Market share can be measured by the company's sales market accounted for the proportion of total sales in segment. In general, the higher the market share, the stronger the profitability. Company which has a larger scale and share of the market control can gain a higher gross margin, lower cost per unit and price stability. Because these companies can share fixed costs with large-scale sales, in addition, the bulk purchase of raw materials will enjoy more preferential discount, so as to make pressure on the market price for its products drop to the lowest. And if the enterprise is facing the situation of market share reduction and also difficult to recruit new customers, at this point, the company's sales will drop; the company's profitability will also be reduced; may cause difficulties of working capital and will soon run into difficulties. Thus, we can consider reducing sales market share and hard to attract new customers as one of the important signs of the impending loss of listed companies.

\subsection{Supply Market Shrinking, Raw Material Price Rising}

Supply situation of the supply market often determines the company's raw material costs. If the raw material of the company supply market is in short supply, and this kind of material is very important to generate material, the company can not find other suppliers and materials for substitution in the case, the material will be at a disadvantage in bargaining, which is bound to the material prices increased brought generate costs increased, and eventually lead to decline in the company's performance or operating loss situation. In addition, if the raw material needed for the company meets a national or global prices rise, then the company will bear the loss of profits due to material price increasing, thereby the likelihood of loss of listed companies are further increasing. Therefore, supply market shrinking and raw material price rising, also become one of the important signs of impending loss of listed companies.

\section{The Current Situation of External Governance Structure}

External corporate governance structure is an external management and control system made up of external market governance mechanism, governance mechanism and social governance mechanism, and regulates the 
authenticity and reliability of accounting information by setting up the social intermediary agencies such as auditing and financial analysis. Since the external governance structure is closely related to the country's macroeconomic regime, with the rapid development of China's market economy, enterprises face increasingly fierce competition of external product market, but still lack competition from capital market, manager market and $M$ \& A market. Manager market and the $M \&$ A market can almost be said yet been established, capital market due to the comprehensive effect of various factors is also imperfect, lack of liquidity compared to the capital market of western developed countries, a significant proportion of state-owned shares can not be real circulation, making the market to constrain managers through a series of mechanisms can play an effective role because managers do not like the managers of the Western countries that constantly threatened from the capital market, "voting with their feet" and " hand vote " pressure. It also lacks a lot of effective conditions to constraint manager, such as investors highly decentralized; distribution of listed companies is not standard; P/E (price/earning) ratio is too low; the investment risk is too large. In this case, most stock price does not reflect the real investment value of the company. In addition, the independent audit as an important system in the corporate governance structure plays a very limited role because our country certified public accountants have deficiencies in the professional technology and professional ethics, etc. Therefore, we can say that our current external corporate governance structure is not rational.

\section{The Loss Signs of Economic Cycle}

The economic cycle is the periodic fluctuation of the national economy, marked by the expansion or contraction of most economy sectors, divided into prosperity, recession, depression and recovery four stages; Among them, the boom and bust are the two main stages, recession and recovery are two transitional phase. Because the driving factor of national economy operation and the connotation of the economic cycle are both different, the duration is usually 2 to 10 years. And at different times, trigger points to promote economic growth are not the same, thus the value of the economic cycle on the company's impact will also vary. In the economic contraction and recovery, prosperity and recession four stages, the stock market is also cyclical fluctuations, therefore, the economic cycle is key to share price movements of the most important factor for a long time, there is empirical analysis show that Chinese stock market volatilize than the macroeconomic cycle volatility about 4-6 months in advance. The long term trend of share price will affect the confidence of investors. If investors expect the economic recovery or boom is coming, they may continue to focus or even increase the investment. Conversely, if investors expect the economy entered a recession, contraction, they may reduce the investment or increase the return on investment requirements, which may increase the cost of funds or miss a good investment opportunity, and ultimately lead to decline in the company's performance suffer a loss. The most important feature of the periodic listed companies whose earnings change with the fluctuations in the economic cycle is great change of gains in a short term, and relying on the entire economic environment. In prosperity, the company's earnings will swell; while in recession, revenue will shrink. Klein and Marquardt (2002) show that the business cycle change is one of the important economic variables causing a loss of listed companies increased frequency. Peter Joos and George A. Plesko (2003) in the study of the possibility of a reversal of loss-making companies put the current growth rate of GDP as a test variable into the model for research, and found that the correlation between GDP growth rate and the possibility of loss reversal is significantly negative, namely that the economic cycle change will affect investors' expectations for future performance of the loss company. Thus, we believe that the recession phase of the economic cycle and GDP growth slow are also signs of impending loss for listed companies (especially cyclical listed company).

\section{The Loss Signs of Industry Development}

The position the life cycle of industry restricts or decides the enterprise's survival and development. Before car birth, Europe's carriage manufacturing was how magnificent, but now, even the auto industry have entered the stabilization period of the life cycle. This means that companies belonging to the industry that has already been in recession can't get rid of the murky prospects however strong their assets and management abilities are. Now who's willing to invest in large-scale carriage production? Investors considering new investments generally will not consider investing in those going into decline and elimination of the "sunset" industries. While picking the stock, investors usually analyze and judge the listed companies issued shares belong to what kind of industry, as well as the period (initial, growth, stability, recession), they generally would not choose to purchase that belongs to recession stocks. Thus, we think, the company in the development of the industry downturn, or in recession, can also be one of the signs of the loss incurred for listed companies.

\section{Results}

It seems that from the external perspective to analyze the loss signs of listed companies appear very important. 
Even in some extent, from the company's external loss signs to identify and analyze the listed companies' losses are more reliable than internal analysis. There are two reasons: first, there is no insider control phenomenon of the company external loss. Compared with loss signs performed within the company (including accounting statements of listed companies, financial indicators, governance structure, management and operation, etc), the loss signs of the audit opinions, product market and external governance structure are often made by organizations or individuals outside the company with reasonable analysis and judgment, representing the objective and impartial standpoint, not manipulating by the companies' management, while the internal signs may be the adjusted results due to the companies' management through earnings management, related party transactions and other means. Therefore, the external loss signs of listed companies can give investors the more realistic, reasonable information. Second, the external loss signs can bring objective and impartial effects. When analyze the company's long-term development, the third party outside the company not only takes into account the circumstances of individual company, but also the company's industry, region and the country's economic cycle. From this point of view, the analysis of the external signs is more open, the overall situation, and more in-depth and long term.

\section{Acknowledgements}

The authors are grateful for financial support from the fund of the Ministry of education of Humanities and social sciences research Youth Project (11YJC630243, 12YJC630010, 13YJC630027), Central University basic research funds in Southwest University (SWU130911, SWU1309202).

\section{References}

Cokkins, D. W., \& Kothari, S. P. (1989). An analysis of intertemporal and cross-sectional determinants of earnings response coefficients. Journal of Accounting and Economics, 11, 143-181. http://dx.doi.org/10.1016/0165-4101(89)90004-9

Das, S., \& Lev, B. (1994). Nonlinearity in the return-earnings relation: Tests of alternative specification and explanations. Journal of Contemporary Accounting Research, 11, 353-379. http://dx.doi.org/10.1111/j.1911-3846.1994.tb00447.x

David, A., Chen, L., Mark, T., \& Brian, W. (2005). Binomial basis for linear information dynamics: Real options, dividends and the valuation of equity. Journal of Accounting and Finance, 45, 323-350. http://dx.doi.org/10.1111/j.1467-629X.2005.00138.x

Du, Y. (2008). Surplus sustainability research review. Journal of Economic Issues, 3, 100-104.

Guohua, J., \& Hansheng, W. (2005). Losses for two consecutive years of listed companies should be "ST"? Journal of Economic Studies, 3, 100-107.

Hayn, C. (1995). The Information content of losses. Journal of Accounting and Economics, 20, 125-153. http://dx.doi.org/10.1016/0165-4101(95)00397-2

Jiang, Y. H. (1999). Change behavior and motives of accounting policy, accounting policy to manipulate profits of listed companies use change case analysis. Journal of China Securities, 10.

Meng, Y. (2004). Relevance empirical study of loss accounting earnings of listed companies. Journal of Accounting Research, 9, 42-46.

Peter, J., \& George, A. P. (2005). Valuing loss firms. Journal of the Accounting Review, 80, 847-870. http://dx.doi.org/10.2308/accr.2005.80.3.847

Xue, S. (2002). How to determine the stock price of the loss companies? Journal of Accounting and Financial, 4, $100-115$.

\section{Copyrights}

Copyright for this article is retained by the author(s), with first publication rights granted to the journal.

This is an open-access article distributed under the terms and conditions of the Creative Commons Attribution license (http://creativecommons.org/licenses/by/3.0/). 